International Journal of Social Sciences and Humanities
Available online at http://sciencescholar.us/journal/index.php/ijssh
Vol. 2 No. 2, August 2018, pages: $243 \sim 251$
e-ISSN: 2550-7001, p-ISSN: 2550-701X
https://doi.org/10.29332/ijssh.v2n2.171

\title{
Royal Figures "Build New Kingdoms" A Picture of Direct Election for Regent/Mayor/Governor in Bali
}

\section{Putu Gede Suwitha ${ }^{a}$}

Article history: Received 10 April 2018, Accepted in revised form 25 July 2018, Approved 15 August 2018, Available online 18 August 2018

\section{Correspondence Author ${ }^{\text {a }}$}

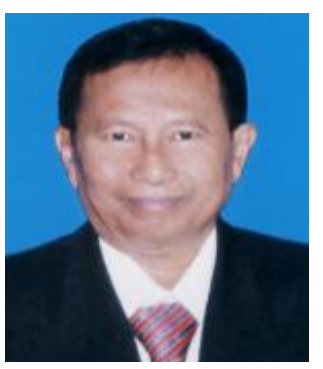

Keywords

Election;

Royal Figure;

Caste System;

Money Politics;

Political Capital;

\section{Abstract}

There is an interesting aspect in the studies of the local leadership in Bali which has not been exposed, namely, the involvement of the royal figures in the direct election for the regent/mayor/governor. The role played by the palace in the selection of leadership in general and in the direct election for the regent/mayor/ government particularly is highly crucial. Before the Dutch people came in the 19th century, the political role played by the royal figures had been known to be prominent. After the expedition made by the Majapahit Kingdom in 1343, which was popularly known as the agricultural feudalistic era during which power was determined by a tight caste system, the political role played by the royal figures was prominent. The fact that one kingdom subjugated another supported social stratification in which the palace became the center of power. This present study is intended to reveal the role played by the royal figure as the symbol of traditional power and its implication on the development of democratic politics in general and the direct election for the regent/mayor/governor in particular after the era of reformation. This study was conducted using the historical descriptive qualitative method. The data were collected through library research, field survey, and in-depth interview. These techniques were used to collect opinions and views on the succession of leadership and were supported by the concept of political culture. The result of the study showed that the royal figure still played a role and appeared in the political affairs, and that some were able to "build new kingdoms" successfully, had been made to disappear for a long time by the national political change. Several royal figures were able to combine economic capital, socio-cultural capital, and symbolic capital as stated by Piere Bourdieu, the French sociologist.

e-ISSN : 2550-7001, p-ISSN : 2550-701X ${ }^{\odot}$ Copyright 2018. The Author. SS Journals Published by Universidad Técnica de Manabí. This is an open-access article under the CC BY-SA 4.0 license (https://creativecommons.org/licenses/by-sa/4.0/) All rights reserved.

a Udayana University, Indonesia 


\section{Contents}

Abstract

1. Introduction

2. Research Method

3. Results and Analysis

3.1 The Palace in 19th-20th Centuries

3.2 The Dynamics of Royal Figure

3.3 The Palace in the Era of Reformation

4. Conclusion

Conflict of interest statement and funding sources

Statement of authorship

Acknowledgements

References

Biography of Authors

\section{Introduction}

As far as the aspect of the local leadership in Bali is concerned, there is one aspect which has not been exposed, namely, the role played by the royal figure in the dynamics of political culture in general and in the succession of leadership in Bali after the era of reformation which started in 1998 in particular. This present study explored the role played by the palace as a symbol of power and traditional strength and its implication on the development of democratic politics in general and the direct election for the regent/mayor/governor in particular.

Before the Dutch people came to colonize in the $19^{\text {th }}$ century, the role played by the palace was popularly prominent politically. The political role played by the palace could be traced when Bali was in the era of agricultural feudalism when Majapahit expanded its territory to Bali in 1343 when the system of power was made in accordance with the tight system of caste (Raka Santeri, 1990). Even after the Gelgel kingdom became disintegrated since the $19^{\text {th }}$ century the royal strength spread widely. New "independent" kingdoms, which used to be the vassals of the Gelgel kingdom, appeared, totaling 8, the same as the total regencies in Bali.

The stratified social structure and formation contributed to the formation of the feudal agricultural culture. The architectural functions of houses, for example, generally adopted the agricultural system. The royal and noble houses were built to be great and luxurious. The form of houses and the language used became stratified between the families with caste and the common people (the peasants). The palaces were built with modern architecture at that time which referred to the Chinese and western architectures.

The houses of those coming from the high caste were built using particular architecture. Such houses were built using bricks and were equipped with great gates, Chinese and Egyptian ornaments and other symbols. Those who came from the high caste also showed that they were different from the common people in regard to the way of social interaction and lifestyle. Particular religious ceremonies, such as cremation ceremony 'upacara ngaben' performed for those coming from the high caste, were made to be great and luxurious. The forms of the performing art performed, such as the gambuh dance and tari legong dance, also symbolized the great nobility.

\section{Research Method}

The historical method was applied in the study analyzed on the sociological approach. The historical method was used to know the dynamics of Puri at times. The analysis of contemporary political sociology was used to explain the power relation of Puri as stated by Foucault (1980). 


\section{Results and Analysis}

\subsection{The Palace in $19^{\text {th }}-20^{\text {th }}$ Centuries}

In the $19^{\text {th }}$ century, a drastic change took place as far as the political constellation of the palaces in Bali was concerned. The wars among the kingdoms took place and things were revitalized. During this period 4 (four) strong kingdoms appeared; they were the Badung kingdom, the Buleleng kingdom, the Mengwi kingdom, and the Karangasem kingdom. The Badung kingdom once controlled the Jembrana and Mengwi kingdoms. The Badung kingdom was rich as it controlled the trading at Kuta. The Mengwi kingdom also once controlled the Blambangan (Banyuwangi) kingdom. Similarly, the Buleleng kingdom did too. Apart from that, the Karangasem kingdom controlled Buleleng and Lombok. Several kingdoms became separated and were taken over by the other kingdoms. However, one kingdom was also unified with another kingdom in order to be more powerful and greater. After this period, in the other context, an intensive relationship was made with the Western (Dutch) world. Then the political history of the palaces in Bali was made characteristically different from that in the previous period. The palace and kingdom were brave enough to and could take part in politics in order to strengthen their power. The Badung kingdom started to work together with the Dutch government. The Badung kingdom gave facilities needed to develop trade in Badung. Mads Lange and NHM were provided with economic concession and trade in Badung. NHM built a trading office at Kuta. Mads Lange, a Danish trader, rented the Kuta harbor and the surrounding areas from the Badung king.

In the $19^{\text {th }}$ century, there were 10 (ten) great kingdoms and each was independent. The revitalization among the kingdoms was becoming strained and wars took place for a long time. In the second half of the $19^{\text {th }}$ century, only 8 (eight) kings existed. They once made an agreement that they would not attack one another due to the influence of the Klungkung kingdom which was considered the symbol of the oldest kingdom (Sidemen, 2002). The agreement made by the kingdoms was popularly known as Pasura Asta Negara (Arsip Nasional RI, 1973). Then the Mengwi kingdom and Payangan kingdom disappeared from the political constellation in Bali. Now Mengwi has appeared again with Mangupura as the new capital of Badung Regency. Badung Regency used to be the government of Denpasar City for a long time.

An extraordinary change took place; in the era of pre-independence and after independence the royal figures "nationally" appeared in the political constellation, as a consequence of the western education far before independence. If compared to the Javanese, Sundanese, and Minang elites, the Balinese elites were under them. In other words, quantitatively and qualitatively the elites of the three ethnic groups underwent modernization before the elites of the Balinese ethnic group. However, compared to the elites of the other ethnic groups, the Balinese elites in general and the royal elites, in particular, had undergone the process of modernization and transformation before them. This was interesting, as, quantitatively, the Balinese ethnic group was small in number. However, the rapid development and the access to the wide network, the elites of Makasar-Bugis, Batakese, Madurese and Aceh ethnic groups are now leaving those of the Balinese ethnic group.

Far before Indonesia became independent, Bali had a royal figure who was a popular national man of letters, namely, A.A. Panji Tisna, a son of the Buleleng king. Then an intellectual from the Ubud Palace, Tjokorda Raka Sukawati, became a valksraad member. Several civil servants such as I.B. Manuaba and I Gst Bgs Oka, who was educated at western school, were appointed the Bali's residents. Bali also had several medical doctors of the first generation before Indonesia became independent such as dr. A.A. Jelantik and dr. I Gst Ngr Gde Ngurah. Militarily, I Gst Ngr Rai, I Gst Putu Wisnu, and I Gst Bgs Suginyar were professional soldiers; they were different from the other soldiers at that time who did not have any military educational background.

When the Independence was about to be proclaimed and after it was proclaimed, the royal figures were getting nationally prominent in the political and governmental affairs. Mr. Ida A.A. Gde Agung and Mr. I Gst Kt Puja showed this. The degree of becoming a national hero was awarded to Mr. I Gst Kt Puja for being actively involved in the sessions held by BPUPKI and PPKI; he also actively took part in the preparation of 1945 Constitution and independence. During the independence era, he was appointed the first governor of Sunda Kecil. Mr. Ida Anak Agung Gde Agung was then appointed a national hero as he was actively involved in diplomacy and foreign and government affairs. The other royal figures in Bali also played important roles in

Suwitha, I. P. G. (2018). Royal figures "build new kingdoms". International Journal of Social Sciences and Humanities, 2(2), 243-251. https://doi.org/10.29332/ijssh.v2n2.171 
the social and government affairs such as I Gst Kt Ranah, I Gst Bagus Sugriwa, Rsi Ananda Kusuma, I Gst Ketut Kaler and so forth.

During the RIS government era, Tjokorda Raka Sukawati, who used to be a Valksraad was appointed the President of NIT (Negeri Indonesia Timur) as part of RIS. Ida Anak Agung Gde Agung was appointed the minister of home affairs of NIT who was based in Makassar. In that era no local people from South Sulawesi who were highly educated. Kahar Muzakar, who was a senior military figure and was highly respected, was only a graduate of Muhamadiyah high school in Solo. Andi Pangerang Peta Rani, a civil servant, was only a graduate of high school. During the Sukarno era, the royal elites in Bali were getting in power. Who was prominent during the Sukarno era was a minister from Bali named I Gst Ngurah Subamia.

During the struggle for independence era, the royal figures were playing important roles. The struggles which were centered in Badung, Tabanan and Buleleng had several militant fighters coming from the royal families. I Gst Ngr Rai, who came from Carangsari, became a national hero. The others such as I Gst Ngr Partha, I Gst Putu Wisnu, I Gst Ngurah Debes, I Gst Ngr Pinda, Dewa Made Suwija and the other royal figures successfully led the Balinese people's struggle against the colonizer.

\subsection{The Dynamics of Royal Figure}

The political development of the royal figures in Bali after the 1945 revolution could be seen in the development of political parties, as what happened in Java. Indonesia's National Party 'Partai Nasional Indonesia (PNI)', which was established by Sukarno, developed in Bali as the biggest political party in the 1960s. It was established by a nationalist from the Satria Palace named Tjokorda Ngurah Agung. The second and third biggest political parties in Bali were Indonesia's Communist Party 'Partai Komunis Indonesia (PKI)' and PSI which was led by the royal figures. After Bali was separated from Sunda Kecil, President Sukarno appointed AA. Bagus Suteja as the Bali's first Governor, although, in the election held by BPH, Nyoman Manti was the winner, President Sukarno chose A.A. Bagus Suteja. Why President chose the royal figures has not been known until now.

The political strategy implemented by the New Order seemed to reduce the role played by the palace in the beginning. Suharto, through the project of political modernization, treated the palace as the center of G elements apart from ABRI and bureaucracy. The political parties were simplified; the only Golkar could be developed. However, finally, Golkar used the group ABG (the Indonesian Armed Forces 'ABRI', Bureaucracy, and Golkar) and still treated the Palace as the G element. What was known as the New Golkar "in the Reformation era" still used the royal figure as a strength? The royal figures who were once approached by Golkar were Tjokorda Pemecutan, who comes from the Pemecutan Palace, Tjokorda Budi Suryawan, who comes from the Ubud Palace, I Gst Ngr Alit Yuda, who comes from the Carangsari Palace, and I Gst Ngr Rai (the National hero).

PDI Perjuangan also collaborated with the royal figures. Historically, PDI Perjuangan was the reincarnation of Partai Nasional Indonesia 'PNI' (Indonesia's National Party) which used the Satria Palace as the center. A.A. Oka Rarmadi, the figure of the Satria Palace, was in opposition to Cokorda Pemecutan, the figure of the Pemecutan Palace who supported Golkar. Ardhana (1993) in his study of the Palaces in Bali stated that there was a sharp competition between the Pemecutan Palace and Satria Palace. The Pemecutan Palace used to affiliate with PSI and then with Golkar. The Satria Palace used to be the center of PNI and now it is the icon of PDI Perjuangan Bali (Suwitha, 1990).

\subsection{The Palace in the Era of Reformation}

Since the Reformation era and the New Order collapsed in 1998, there had been a crucial political change in the Balinese community. New discourses which raised various societal problems with a new paradigm were created. The local underwent a new phase of life, namely, emancipation which could not be imagined in the previous eras.

The trend which was interesting in politics was the appearance of the discourses which intended to cause the royal figure to appear in the succession of leadership which had been neglected before. The royal figure was still regarded as a symbol and at least had a moral strength to maintain the society's morality which had undergone the euphoria of freedom after having been shackled for a long time by the authoritarian leadership 
during the new order. Although the royal strength had been within the center of power for a long time, the discourses and the news in the media still motivated the royal figures to appear dramatically. It was reported in the local newspaper that "the Karangasem Palace had prepared its candidate democratically. It was exposed in the local mass media that the "Karangasem Palace had prepared its candidates" for the general election for the regent. "The Strength of the Gianyar Palace became weaker when Cok Nindya chose AA Bhrata's younger brother as the candidate of deputy Gianyar Regent". In this case, Cok Nindya, the figure of the Peliatan Palace, was the rival of AA Bharata, the figure of the Gianyar Palace. They were nominated by two different political parties as quoted from the local newspaper when the general election for the regent was about to be held. (Harian Nusa, 26 Maret 2010).

The direct election for the regent was a new phenomenon. Many people did not recognize that since 2004 we had had a new culture and a new era. We were given a new visa that we were allowed to choose our leaders independently and democratically, transparently and justly through a direct general election.

The general election as described above was impossible in the previous eras; the leaders recommended should be elected and accepted; we were not allowed to elect the leaders who were not recommended. Space has been widely opened; we have been able to determine whom should be elected for the regent, deputy regent, and even president. The implication has been that people should be ready to have new leaders. In this new era, the leaders who appear should at least have 3 (three) basic capitals. In other words, when someone would like to be a leader he should have 3 (three) basic capitals; they are morality, ability, and strength (money capital). Then we have recognized that we do not have many civil cadres whose morality can be used as a model; we do not have many civil cadres who are highly knowledgeable, intelligent and financially strong. It is these three strengths which empower people (Handayani).

We do not recognize that we have followed what is referred to as the military supremacy rather than civil supremacy. The shift from the military figures to the civil figures has been responsible for the limited number of existing civil cadres. As a result, the civil royal figures have been used as one alternative. It is legal that the royal figures have appeared. The palaces still have adequate human resources. Apart from the educational and economic point of view, the Palaces still have the "shine" in the form of ethic and moral strength, which have been neglected recently.

Now all the royal political strengths, which were disappearing for a long time, have been reconstructed again. The royal strength and power have been made to disappear by the political-economic change due to the economic crisis taking place in the 1930s, the Japanese colonization, and World War II, the struggle for independence and the economic-political problems which took place in 1950s and 1960s.

Since 1970, economically Bali has become better especially in regard to tourism. The palaces still have strong human resources. The Palaces still have strong resources; they still have human resources and much land. Several palaces have developed various businesses of tourism. Finally, the royal image has been developed socially, culturally, religiously, historically and so forth. The palace's image has been formed through more delicate things and traditional values such as helping renovate temples, helping traditional villages and other religious ceremonies. Such an image has also been formed through the palace's ability to build a social network and work for people (social capital). When the people come to the palace, they are always welcome. The palace has never refused what is asked for by the people. They usually go to the palace to ask for advice, information and historical explanation. In this case, the people feel deeply indebted. When there is a ceremony performed at the palace, the people come to be involved in the ceremony without expecting for any pay. The assistance given in the form of traditional, religious and historical advice constitutes the strength under the category "knowledge is power". This is the basis of the traditional political system in South East Asia, which have been explored by several experts such as J.M. Gullick conducting his research in Kalimantan, Ben Anderson, Sumarsaid Mexico, Milner, Srieke in Java, and Geertz and Nordholt in Bali. It is very interesting that such a traditional system is still strong in the globalized era. In addition, the Palace still has hegemony or ideology to support, look after, and justify its position. Through a sophisticated process, the palace has obtained his past power which had been disappearing for a relatively long time. The "New Kingdom" has been adopted from the military strength and political strength through the wider impact on the traditional, religious, historical and scientific domains. The capital of leadership does not only include wealth (red. land) and power but also culture. Francis Fukuyama refers to it as social capital. In Bali, the people also obtain protection and information apart from material capital (artadana). A French sociologist, Piere Bourdieu, refers to it as symbolic capital apart from economic capital. The symbolic capital includes

Suwitha, I. P. G. (2018). Royal figures "build new kingdoms". International Journal of Social Sciences and Humanities, 2(2), 243-251. https://doi.org/10.29332/ijssh.v2n2.171 
belief, prestige, reputation, and name heritage. The material capital is only an instrument used to obtain symbolic capital, which is still strong in South East Asian and in our political future. Our society is still a transitional one which still maintains traditional things. C. Geertz (1980) refers to it as a Symbolic Play, namely, superiorities are shown through great and luxurious ceremonies rather than through material power. According to Bourdieu, the symbolic capital and economic capital can complete each other and cannot be separated from each other. The non material capital includes caste, reputation, prestige and the people's belief. Such symbols can build the image of a leader in a paternalistic society.

Several royal figures have been able to "build new kingdoms" which can combine the capitals stated by Bourdieu such as economic capital, social capital, cultural capital and symbolic capital. The economic capital plays an important role in the direct general election, in which it is referred to as "political cost" rather than money politics. A political figure is obliged to go for what is called "simakrama" to every banjar (the smallest traditional neighborhood after a traditional village), traditional village and other traditional organizations. This is the political cost they should bear. Although simakrama is referred to as a symbolic coercion (Bawa Atmadja, 2002), the social capital can also build a significant social network and a network of brotherhood; similarly, the cultural capital, the cultural capital such as academic degree can too. Not every palace in Bali has economic resources. The Ubud Palace has a lot of lands to rent. The Gianyar Palace has been able to perform spectacular religious ceremonies as the symbolic power. The symbolic capital and economic capital can complete each other.

A royal figure from the Mengwi Palace has been a regent for two periods. This fact seems to discontinue the historical curse, much of which is mentioned in the local sources. The king of the Mengwi kingdom once killed Prince Wilis at Seseh Beach, Badung, although He, who was also called Mas Sepuh), the king's son whose mother came from Blambangan. The curse lasted until the seventh generation. The royal figure from the $8^{\text {th }}$ generation of the Mengwi kingdom has appeared as a prominent strength.

The royal figure from the Satria Palace (Denpasar) has also been a political icon in Bali. Initially, it was the palace of struggle and the place where PNI Bali was born; now it is the center of PDI Perjuangan Bali. The royal figure of the Satria Palace has been a legislative member several times and now, in the era of the government of Joko Widodo, the Minister of Cooperative is also from there. The royal figures from the Ubud Palace and Gianyar Palace have been the regent of Gianyar Regency several times. The Gianyar Palace is the center of PDIP Gianyar and the Ubud Palace is the center of Golkar Political Party. I Gusti Ngurah Alit Yuda, a son of I Gst Ngr Rai (the national hero), has been a legislative member of the Republic of Indonesia and Head of Bali Golkar for several periods.

\section{Conclusion}

It has been a fact that several palaces have not been politically involved in the era of the direct election. It is possible that they have not been able to make use of the resources as what is stated by Bourdieu. As the theory proposed by C. Geertz that in several regions there are palaces which are maintained as the cultural as well as symbolic heritages; however, in the other regions, a dramatic transformation has taken place, meaning that the palaces are used as the economic capital. The economic capital is not always reliable, as its position and the position of cultural capital, symbolic capital and other social capital must substitute for one another.

Finally, it can be stated that the traditional roots are still strong in the political system in Bali. Tradition is a heritage which will never die and become a fossil. It is a dynamic heritage from the past. If we build a new political system in the future, we should not be too far from the roots of the old culture as mentioned above. What is modern and new is not necessarily copied from the western system; similarly, when we build a democratic system. What was found interesting from the moral strength and truth of the palace is still reliable; the fact that the royal figures are seldom involved in any legal case proves this. 
Conflict of interest statement and funding sources

The author declared that he has no competing interest. The study was financed by the author.

Statement of authorship

The author has a responsibility for the conception and design of the study. The author has approved the final article.

Acknowledgments

The would like to thank the editor of IJSSH for their consideration to publish this article. Thanks for their support, valuable time, and advice. 


\section{References}

1. Ardhana, I. K. (2013). Pandangan Lokal Versus Barat Tentang Puputan Badung: Ekspansi Imperialisme Modern Belanda dalam Konteks Bali. Journal of Bali Studies, 3(1).

View in (Google Scholar)

2. Ardhana. (1993). Balinese Puri in Historical Perspektif. Thesis Master, The ANU, Canberra. View in (Google Scholar)

3. Arnawa, I. K., Martiningsih, G. A. G. E., \& Sukerta, I. M. (2017). Development Concept Plan of Minapolitan Regions in Gianyar Bali Indonesia. International Research Journal of Engineering, IT and Scientific Research (IRJEIS), 3(6), 11-20.

View in (Google Scholar)

4. Arsip Nasional. Surat-surat Perdjandjian Antara Kerajaan-kerajaan Bali / Lombpok Dengan Perintah Hindia Belanda. 1841-1938. Djakarta : Arnas.

View in (Google Scholar)

5. Atmadja, A. T., Ariyani, L. P. S., \& Atmadja, N. B. (2016). Women as Canang Sari Street Vendors in Bali. Komunitas: International Journal of Indonesian Society and Culture, 8(1), 85-93.

View in (Google Scholar)

6. Foucault, M. (1997). What is critique. The politics of truth, 2382.

View in (Google Scholar)

7. Geertz, C. (1980). Negara. Princeton University Press.

View in (Google Scholar)

8. Mardika, I. N. (2017). Opposition of Community Citizenship Against the Policy of the Village's Leader. International Journal of Social Sciences and Humanities, 1(3), 74-87.

View in (Google Scholar)

9. Raka Santeri. 1990. Kesalahan Pemakaian Kasta Berabad-abad. Denpasar : Manikgeni. View in (Google Scholar)

10. Sidemen, I. B. (2002). Nilai historis uang kepeng. Larasan-Sejarah.

View in (Google Scholar)

11.Suada, I. N. (2018). Transformation of masatia tradition towards Hindu religion in Bali. International Journal of Social Sciences and Humanities, 2(2), 226-242.

View in (Crossref)

12. Suwitha, I. P. G. Elite Puri dalam Lanskap Politik Kontemporer di Bali. Journal of Bali Studies, 5(1). View in (Google Scholar) 


\section{Biography of Author}

\begin{tabular}{|l|l|l|}
\hline \hline & Dr. I Putu Gede Suwitha, S.U is a teaching staff at Faculty of Historical and Cultural \\
Science in University of Udayana, Bali. He has finished his Bachelor and Magister \\
Degree at University of Gadjah Mada, Yogyakarta. There were some researchers that \\
conducted e.g. in South Sulawesi he studied about History and Bugis Culture for two \\
years, in 1989-1991 and the research was conducted in ANU (Australian National \\
University), Canberra, in 1991. He adhered an International Seminar in University of \\
Gadjah Mada, Yogyakarta in 1988, Canberra (1991), Wollongong (1995), Sydney \\
(1995), University of Yogyakarta State (2014), Bangkok (2015). He as well as to have \\
more than 100 scientific research, books, articles, and poster. \\
Email: dmasita_kiz27@yahoo.co.id / putu_suwitha@yahoo.co.id
\end{tabular}

Suwitha, I. P. G. (2018). Royal figures "build new kingdoms". International Journal of Social Sciences and Humanities, 2(2), 243-251. https://doi.org/10.29332/ijssh.v2n2.171 